\title{
REVIEWS ABOUT SOME LANGUAGE FEATURES OF THE COLLECTION OF ESSAYS "WHAT I LOST AND FOUND"
}

\author{
Lobar Abdiaziz Kizi Abdushukurova \\ Independent Researcher, Samarkand State University, Uzbekistan
}

\section{ABSTRACT}

The present article discusses some language features of the essay collections "What I Lost and Found" by Uzbek prominent author Said Ahmad who gave a birth of many humoristic stories that expresses the life and some tradition of Uzbek people.

KEYWORDS: - Essay, artistic-publicistic genres, Russian-Uzbek Explanatory Dictionary of Literary Terms, Latin, Mushtum magazine, Kizil Uzbekistan, Sharq Yulduzi.

\section{INTRODUCTION}

The essay was also considered a scientific object of literary studies as a genre of literature. The essay, which is among the artistic-publicistic genres, has its own characteristics. The term "essay" is interpreted differently in different literatures. In particular, the Explanatory Dictionary of the Uzbek Language describes it as "Essay" (French essay-experiment, exercise, and sketch) is a prose work written on literary, philosophical, social, journalistic and other topics, in which problems are interpreted freely, not in a systematic scientific way", while the "Russian-Uzbek Explanatory Dictionary of Literary Terms" defines it as "Essay-Latin exigoderived from the words I guess, I measure, have a free composition; a small work that expresses personal opinions and views on specific topics...". Although the essay began to be created in Uzbek literature in the 70-80-ies of the XX century, it was originally used as a genre in the work of the French philosopher Mishel Munten "essay" ("studies"). This work of Monten, which has reached US, consists of three books; it was created in 1580-1588-th year. "Essay" is a Latin word, which means "conducting an experiment on you". Here's what Munten writes about the essay: "The plot of my book is that I am my own".

\section{T HE MAIN FINDINGS AND RESULTS}

To date, many essays have also been written in Uzbek literature. One of these is Said Ahmed's collection of essays "What I lost and found". This collection of essays has become an excellent example of the genre of essays, which has its own merits. This work was re-published in 2014 by the publishing house "Sano Standard" in the authorship of the writer's daughter Nodira Husankhojayeva. 
CURRENT RESEARCH JOURNAL OF PHILOLOGICAL SCIENCES 2(7): 32-35,

May 2021 DOI: https://doi.org/10.37547/philological-crjps-02-07-08

ISSN 2767-3758

(C)2021 Master Journals

\section{Crossref do) 8 Google}

Accepted26 thJuly, 2021 \& Published 31 thJuly, 2021

In this regard, let us dwell in more detail on the path of life and creativity of the famous writer.

One of the leading figures of the Uzbek prose, Said Ahmad Husankhujaev, was born on June 10, 1920 in the Samarkand Darvoza mahalla of Tashkent. In 1939 he graduated from high school, and in 1943 he graduated from a higher educational institution. In Literature lessons and circles, his enthusiasm for creativity increased, holding a pencil in his hand. And the time press was a school of his creativity.

Said Ahmad initially worked in "Mushtum" magazine, Radio committee (1942-1943), "Kizil Uzbekistan" newspaper (1943-1947), "Sharq Yulduzi" magazine (1948-1950).

His first collection of stories "The Gift" is published in 1940 year. Said Ahmad in recent years from the war and the war has written many felieton, essays and stories. His collections such as "Earth heart" (1942), "Fergana stories" (1948), "Love" (1949) were published. He excitedly describes the terrible consequences of the Second World War in his stories like "Treasure", "Scream", "Thank you, my dears", glorifying the heroes of the war. In the stories of the writer, Oybek's psychological image skills, Gafur Gulom humor, Abdulla Kahhor laconism are embodied in the description.

All the stories of Said Ahmad are written on a modern topic. He seeks to draw a philosophical generalization from each of the events described in his stories, to express events with lyrical expressiveness, to achieve the diversity of artistic images. A number of works such as "Desert Eagle", "Apricot Teacher", "Falcon", "Man and Wolf", "Flower Garden", "Toyboshi - The Head of Ceremonies" were news both in the creativity of Said Ahmad and in Uzbek prose. The inner world of the protagonist of the literary stories is our rich contemporaries. The writer created life characters in the works "The Legend of the Mountain", "Emerald", "Birth of Love",
"There was fire in your eyes", "Standing", "Lullaby", "Lights of Good Fortune". Said Ahmad laughs at the bad traditions that are hindering our progress in his satanic stories, exposing important spiritual issues. His dozens of volumes, such as "Khanka and Tanka", "Lamp Bottle", are evidence of our thoughts.

Said Ahmad founded the theatre of cheerful miniatures on Uzbek radio and television with his works of small humor.

Said Ahmed passed from the stories gradually to the creation of large poles. In the novel "Horizon" (1964), created after the stories "The Precious Fields" and "Judgment" (1958), published in 1949, he told the story of the heroes of Labor, which he showed behind the front lines of the Uzbek peasants in the fiery years of the Second World War. "Horizon" is a trilogy, in which the writer argues about the problems of the pre-war and post-war period. And in the novel "Silence" (1988) seeks to expose the vices of the period of stagnation.

Said Ahmad is also known as a playwright. He is the author of such stage works as "The Bride's Revolt", "The Bridegroom".

Said Ahmed is also a creator who suffered the second wave of the cataclysm period, suffering lager torments.

Many of author's stories have been turned over to fraternal and foreign languages. Said Ahmad was awarded the titles of People's Writer of Uzbekistan (1980), Honored Worker of Culture of Uzbekistan (1968), and the Hamza Prize. He was awarded the Order of Merit for his great services (1997) and "Order of Friendship" (1996). He is also the Hero of Uzbekistan (1999).

He died on December 5, 2007 in the city of Tashkent. Said Ahmad has long been together with outstanding literary figures, which have now become unitary memories in Uzbek literature. They have collaborated on trips. In the 
CURRENT RESEARCH JOURNAL OF PHILOLOGICAL SCIENCES 2(7): 32-35,

May 2021 DOI: https://doi.org/10.37547/philological-crjps-02-07-08

ISSN 2767-3758

(C)2021 Master Journals

\section{Crossref do) 8 Google}

Accepted26 thJuly, 2021 \& Published 31 thJuly, 2021

light of these unique people behind the Uzbek people, they were with them both in their days and moments of suffering. There are no literary tissues in the memories; the described events are a pure fact, carefully observed, passed through the sharp eye of the writer.

The work can be divided into three parts in composition. Each part merges under a big heading. They can be called specific chapters. For example, the teachers mentioned in the part of the first chapter "What I Lost..." and described with great affection no longer exist; they left valuable Knights to the Uzbek people, the artistic treasure of their homeland and went to extinction. The second part of the book is called "What I found...". In this chapter, boiling thoughts are expressed in the words of writers who are worthy of people's respect, Utkir Hoshimov, Nemat Aminov, Togay Murod, Nosir Fozilov and others. In this sense, the name of the work is quite consistent with its internal meaning.

Chapter three describes the author's sufferings, impulsive thoughts on the confession, which he found with a lot of hard work, in which the author spent days without light of light of light of light.

We touched on the title of the work, which is one of the means of composition, above. It is also worth noting that the work also consists of small titles under large titles. For example, the essay about Abdulla Kahhor consists of headlines such as "The Creator Who Shouldered the Truth", "A Thousand and One Souls", "The Lost Book", "Creativity and Courage", "Lesson".

To further clarify the meaning of the titles, the writer also used epigraphs wisely. In the game the following epigraphs are presented: The splendor of opportunity is king rows-la, embellish lifetime notebook. (An essay about the Ghafur Ghulam), the period that passed, the period that went as possible, no longer records the periods (an essay about the
Oybek), all became prosperous, did not become prosperous dust (an essay about Shukhrat) and others.

The language and style of this essay are also unique. This essay is written mainly in a scientifically popular style. Because it also has the characteristics of both a scientific style and a popular style. But in this way we cannot say that the features of the artistic style in the essay are absent, because every created artistic work reflects artistry in the first place. The essay contains the main extra-linguistic symptoms, such as clarity of statement, logical consistency, objectivity, compactness, and individuality, comparative, characteristic of the scientific style.

For example, words are used mainly in one meaning, from the options in the synonym series, the appearance of which is clearly expressed in the essence of the matter is chosen. In the essay about Maksud Sheikhzade, Sheikhzoda is described as follows:

He was a scholar poet

He was a poet scholar

("What I lost and found"; p. 154). In this place, the author would have used synonyms such as a linguist, a literary critic, a writer, a playwright in place of the words "scholar" and "poet". However, reducing the scientific and artistic value of this work, the true essence of the Sheikhzade activity was not revealed. Therefore, the author clearly says the poet-scientist, scientist-poet.

The essay covers modern, topical, socio-political, household themes of the popular style. In the essays about Abdulla Kahhor, Gafur Gulom, especially such topics are fully covered.

For example, essays with the title "The Poet's Wife", "Tears of Joy" reflect more of the hero's household life than content, essays such as "the continuation of the Shum child", "Birth of Time" have a socially-popular character. In general, 
CURRENT RESEARCH JOURNAL OF PHILOLOGICAL SCIENCES 2(7): 32-35,

May 2021 DOI: https://doi.org/10.37547/philological-crjps-02-07-08

ISSN 2767-3758

(C)2021 Master Journals

Crossref do: 81 Google

Accepted26 th July, 2021 \& Published 31 ${ }^{\text {th }} J u l y, 2021$

when reading these essays you will come to your eyes not a famous writer or poet, but an ordinary person. The creators depicted in it will be able to more accurately tell the features that we do not know, "secrets". For example, reading the essays about Abdulla Kahhor, we can be sure that this creator was the head of the strict family in life.

In the essay, the author revealed new facets for linguists, using words that are characteristic only of his style. It is not surprising that these neologisms serve as the basis for new research. Said Ahmed's work, which we are studying, will still, is the basis of hundreds of scientific works. This work, as a rare treasure of Uzbek literature, has become an important source and basis for linguistics as well as literature.

\section{Conclusion}

Said Ahmad's work is like an ocean. His essays in "What I Lost and Found" are a drop in the ocean. This article provides only some general comments on the compositional structure, language, and style of the essay. Other linguistic features of this perfect work will be interpreted in our later studies.

Said Ahmad's creativity is like an ocean of fur. His essay, which he entered in the book "What I Lost and Found", is a drop from this sea. This article provides only some general comments on the compositional structure, language, and style of the essay. Other linguistic features of this perfect work are interpreted in further research.

\section{REFERENCES}

1. Annotated dictionary of the Uzbek language. State Scientific Publishing House "National Encyclopedia of Uzbekistan", 2008, Volume 5. - p. 92. (O'zbek tilining izohli lug'ati. "O'zbekiston milliy ensiklopediyasi" Davlat ilmiy nashriyoti, 2008-yil, 5-jild. - 592b)
2. N.Hotamov, B.Sarimsoqov. (1983) RussianUzbek Glossary of Literary Terms Tashkent: "Teacher". (N. Hotamov, B.Sarimsoqov. Adabiyotshunoslik terminlarining ruscha-o'zbekcha izohli lug'ati - T:"O‘qituvchi" 1983-yil.)

3. National Encyclopedia of Uzbekistan. State Scientific Publishing House "National Encyclopedia of Uzbekistan", 2005, Volume 10. (O'zbekiston milliy ensiklopediyasi. "O'zbekiston milliy ensiklopediyasi" Davlat ilmiy nashriyoti, 2005-yil, 10-jild.)

4. Said Ahmad. (2014) What I lost and found. Tashkent. "Sano Standard" Publishing House. - p. 352. (Said Ahmad. Yo'qotganlarim va topganlarim. Toshkent "Sano Standart"nashriyoti , 2014-yil-352b) 